\title{
Diet shifts of Rhizoprionodon terraenovae from the southern Gulf of Mexico: possible scenario by temperature changes
}

\author{
Javier E. Viana-Morayta ${ }^{1}$, Yassir E. Torres-Rojas ${ }^{2}$ \& Jaime Camalich-Carpizo ${ }^{3}$ \\ ${ }^{1}$ Maestría Multidisciplinaria para el Manejo de la Zona Costero-Marina, Instituto de Ecología \\ Pesquerías y Oceanografía del Golfo de México, Campeche, México \\ ${ }^{2}$ Instituto de Ecología, Pesquerías y Oceanografía del Golfo de México, Universidad Autónoma \\ de Campeche (EPOMEX, UAC), Campeche, México \\ ${ }^{3}$ Strängnäs, Södermanland County, Sweden \\ Corresponding author: Yassir E. Torres-Rojas (yetorres@uacam.mx)
}

\begin{abstract}
The current study examined the stomach contents of the Atlantic sharpnose shark (Rhizoprionodon terraenovae) in the southern Gulf of Mexico during 2015 to understand the relationship between diet and changes in sea surface temperature (SST). Prey-specific index of relative importance (\%PSIRI), diet breadth (Bi), trophic level (TrL), and trophic overlap (PERMANOVA) were calculated between sexes, body size, and climatic seasons (dry, rainy and winter storm). The lowest temperature recorded in the area was during February $\left(23.9^{\circ} \mathrm{C}\right)$, and the highest was during August $\left(29.1^{\circ} \mathrm{C}\right)$. A total of 124 stomachs were analyzed, with $54.84 \%$ containing food. The trophic spectrum was composed of 32 identified prey, with demersal fish (Haemulon plumierii; \%PSIRI $=22.82$ ) and pelagic fish (Sardinella aurita; \%PSIRI = 12.83) being the most important. According to the diet breadth $(B i=0.002)$, Costello's graph, and trophic level $(\mathrm{TrL}=$ $4.2), R$. terraenovae is a specialist tertiary consumer. PERMANOVA indicated significant trophic differences between sexes $(\mathrm{F}=32.22 ; P<0.05)$, body size $(\mathrm{F}=13.68 ; P<0.05)$, and among climatic seasons $(\mathrm{F}=23.86$; $P<0.05)$. Spearman's correlation indicated a negative relationship between the diversity of prey consumed by $R$. terraenovae and sea surface temperature $(r=-0.75 ; P<0.05)$. Therefore, diet for $R$. terraenovae is associated with SST, allowing for the development of possible scenarios related to climatic phenomena like climate change.
\end{abstract}

Keywords: Rhizoprionodon terraenovae; sharks; stomach contents, SST; ecology; climatic change; Campeche

\section{INTRODUCTION}

Seasonal abiotic variations may influence the life cycle and distribution of many marine species (Laurs \& Lynn, 1977; Weihaupt, 1984). Fish, in particular, generally respond quickly to changes in physical and chemical conditions (e.g., temperature or salinity). Some authors indicate that temperature changes could influence factors like prey availability and abundance (Hart \& Ison, 1991; Stergiou \& Fourtouni, 1991; Brewer \& Warburton, 1992), causing changes in the structure and function of a community (Odum, 1970; Begon et al., 1995). Thus, climate variability and climate change impacts on marine species have become a new focus of research for numerous ecosystems (Hobday et al., 2013).
Shark species are part of a diverse class of predators fulfilling an important function within the structure of marine and coastal ecosystems (Stevens et al., 2000; Carrier et al., 2010), as final energy receptors (Myers et al., 2007; Heithaus et al., 2010). Some shark species have been used as indicators of changes in sea surface temperature (SST) through the study of their distribution (Brenes et al., 2000) and changes in diet (Musick et al., 1993). These characteristics allow for elasmobranchs to be used as bio-indicators of changes in the ecosystem due to their wide distribution within the water column (Carrier et al., 2004; Priede et al., 2006).

The Atlantic sharpnose shark (Rhizoprionodon terraenovae), is a viviparous placental species (Compagno et al., 2006), which aggregate to mate and

Corresponding editor: Alejandra Volpedo 
give birth between March and June (Pérez-Jiménez \& Méndez-Loeza, 2015). Probably associated to different environmental (sea temperature preference) and biotic factors (providing protection and feeding conditions) in different protected natural areas such as the Reserva de la Biosfera de "Los Petenes," southern Gulf of Mexico (particularly in Campeche coast) (Pérez-Jiménez \& Méndez-Loeza, 2015).

Knowledge of diet shift and its relation with SST variation through time could provide a better comprehension of the structure and function of marine communities and ecosystems in this area and elsewhere. There are few studies related to the effects of temporary variation of diet in different marine species. According to Cortés et al. (1996), Sphyrna tiburo of the Florida coast presents changes in diet with climatic seasons. Other species of elasmobranchs, such as $R$. terraenovae, is considered a bentopelagic generalist species. And its diet is represented by preys with higher availability and abundance in the capture area, presenting changes in their diet according to the ontogenic state (Bethea et al., 2006). However, as with other shark species, data on the diet shift and its relation with SST variation is scarce, and more information, particularly regarding trophic interactions in a temporal scale, is needed for the southern Gulf of Mexico.

It is important to consider diet shift and climate variability when assessing variability in exploited species like $R$. terraenovae to establish possible scenarios when designing management responses to climate or fishery threats. In this context the objective of this study is threefold: i) identify the diet of $R$. terraenovae based on the analysis of stomach contents to detect possible intraspecific differences (sex, body size and climatic seasons) in the diet; ii) evaluate diet breadth, trophic overlap and trophic level; and iii) correlate the diet with the sea surface temperature. These results will allow for the evaluation of the relationship between $R$. terraenovae diet and environmental changes, to generate scenarios of the possible impacts that may occur (positive or negative) for this species of elasmobranch in the presence of phenomena such as climate change.

\section{MATERIALS AND METHODS}

Samples from small scale gillnet fishing boat (30 boats) artisanal landings were collected during 2015. The fishing units were fiberglass boats with lengths of 8 to $10 \mathrm{~m}$ (Martínez-Cruz et al., 2016) operating in the southwest of the Reserva de la Biosfera de "Los Petenes" (RBLP), located in the northwest region (Fig. 1) of the State of Campeche (CONANP, 2006). This region presents three seasons: a dry season (February to
May), a rainy season (June to September), and a winter storm season (October to January) (Yáñez-Arancibia \& Day, 1982).

Once the sharks were identified, total length (TL) in $\mathrm{cm}$, sex, and approximate catch area were recorded. Subsequently, a longitudinal section was made in the ventral part of each organism to remove the stomach. Then stored in labeled plastic bags and transported for analysis in the Trophic Ecology Laboratory of the Instituto de Ecología, Pesquerías y Oceanografía del Golfo de México (EPOMEX Institute) in San Francisco de Campeche, Campeche.

Stomach fullness percentage of stomachs was determined according to the gravimetric method described by Stilwell \& Kohler (1982), where $0=$ empty, $1=1-25 \%$ full, $2=26-50 \%$ full, $3=51-75 \%$ full, and $4=76-100 \%$ full. The digestive state of the prey species was noted according to the digestive levels described by Galván-Magaña (1999): 1: includes items recently consumed; 2 : items with little or no remaining skin; 3: presence of fish skeletons; and 4: presence of hard structures such as fish otoliths, crustacean remains and cephalopod beaks to identify them to the smallest possible taxon. Fish were identified with the taxonomic keys of García-Godos (2001) and Carpenter (2002). The crustaceans were identified with the keys of PérezFarfante \& Kensley (1997) and Tavares (2002). The cephalopods and cephalopods beaks were identified with the keys of Wolff (1984) and Clarke (1986). The collection of otoliths, fish vertebrae, and cephalopod beaks available in the fishing laboratory of EPOMEX Institute were also used.

Once the stomach content of each organism was identified, we determined whether the number of stomachs analyzed was adequate to represent the diet of Rhizoprionodon terraenovae. Diversity of prey species cumulative curves (DPSCC) (Ferry \& Cailliet, 1996) were created by sex, body size, and climatic season with the EstimateS program (Colwell, 2006). As a degree of variability in diet indicator, the coefficient of variation (CV) (Steel \& Torrie, 1992) was calculated. For this study, we consider a coefficient of variation $<0.05$ (little data dispersion) suitable to represent the diet of $R$. terraenovae.

To detect intraspecific diet variation, we sorted $R$. terraenovae data by sex, body size (group $1=37-75 \mathrm{~cm}$ TL; and group $2=76-102 \mathrm{~cm}$ TL; Murdy et al. 1997 and García, 2014) and climatic seasons (dry, rainy and winter storm). The data of the diet was calculated as a mean proportion by number $(\% \mathrm{MN})$, weight $(\% \mathrm{MW})$, and frequency of occurrence $(\% \mathrm{FO})$ for individual sharks, and subsequently averaged for each type of prey as described by Chipps \& Garvey (2007). The preyspecific index of relative importance (\%PSIRI) (Brown 


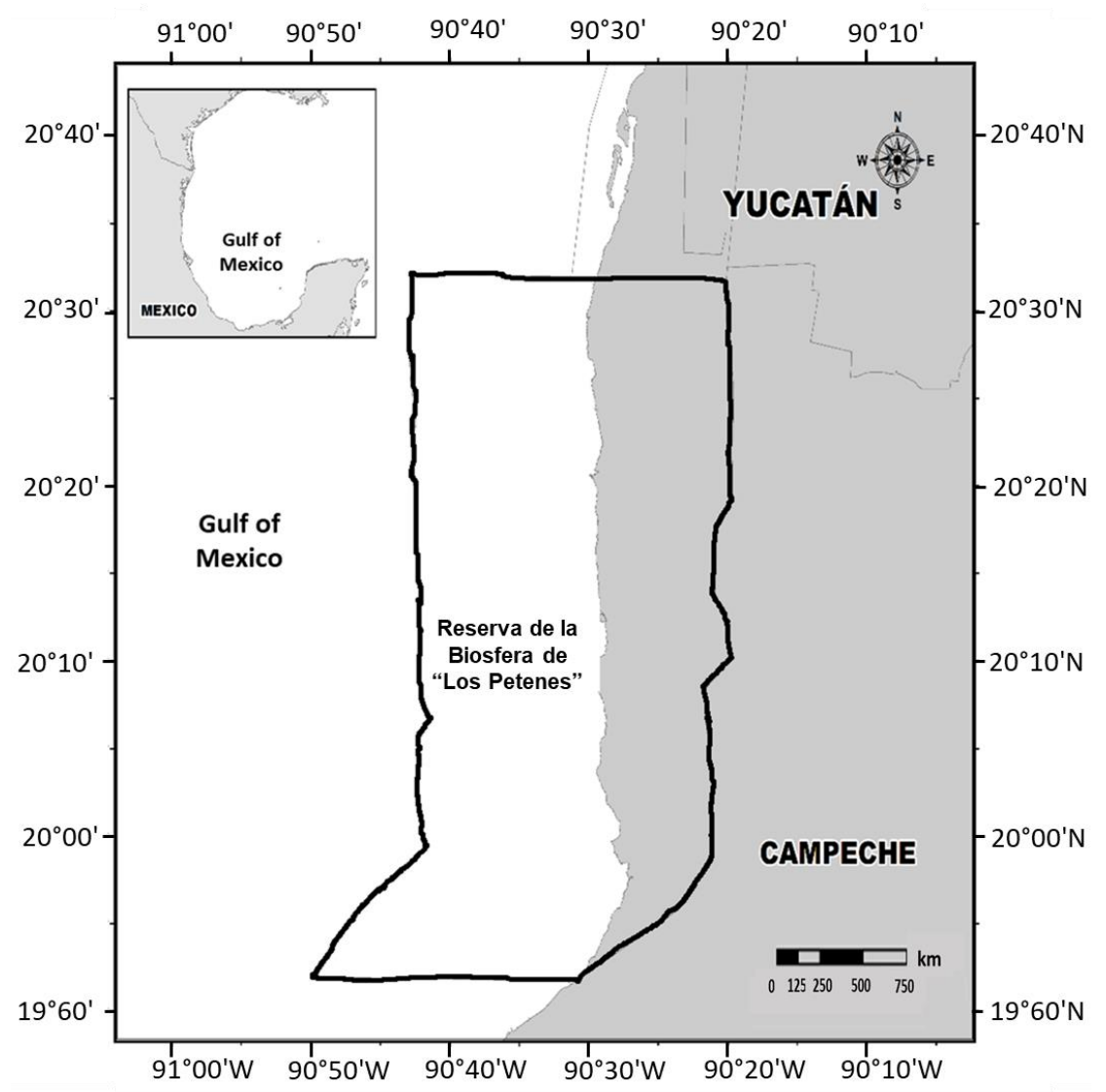

Figure 1. Study area and fishing area. The black line represents the area of the Reserva de la Biósfera de "Los Petenes", San Francisco de Campeche, Campeche, México.

et al., 2012) was used to determine the importance of each prey in the diet according to the equation:

$$
\% \text { PSIRI }=\frac{\% \mathrm{FO} \times\left(\% P_{N i}+P_{W i}\right)}{2}
$$

where: \%FO represents the frequency of occurrence percentage (the number of stomachs containing prey $i$ divided by the total number of stomachs, $\mathrm{n}) ; \% \mathrm{P}_{\mathrm{Ni}}$ and $\% \mathrm{P}_{\mathrm{Wi}}$ represent prey-specific abundances by number or weight, respectively. \%PSIRI is a modification of the index of relative importance (IRI) (Pinkas et al., 1971).

The breadth of $R$. terraenovae trophic niche was evaluated using Levin's standardized index, $B i$ (Krebs, 1999). $B i$ in value ranged from 0 to 1 , with low values $(<0.6)$ indicating a diet dominated by few prey types (i.e., a specialist predator) and higher values (>0.6) positioning it as a generalist predator (Labropoulou \& Eleftheriou, 1997):

$$
B i=\frac{1}{n-1\left\{\left(1 / \sum \mathrm{P}^{2} \mathrm{ij}\right)-1\right\}}
$$

where $\sum \mathrm{P}^{2}{ }_{i j}$ is the proportion of the diet of the predator $i$ that consumes prey $j$, and $n$ is the total number of prey species.
The feeding strategy was also evaluated graphically using the graphs of Costello (1990) modified by Amundsen et al. (1996). These authors propose four population strategies: population A, specialize in individual prey types. As a result, these fish show a high degree of between-individual variation in diet breadth. In population $\mathrm{B}$, predators have a more generalized diet and higher within-individual variation in diet breadth. In population $\mathrm{C}$, the predator population is specializing in a single prey type while occasionally consuming other prey. Finally, population D represents a mixed feeding strategy in which some individuals have a specialized diet, and other fish have a more generalized feeding strategy (Fig. 2).

The trophic level was calculated using the equation proposed by Christensen \& Pauly (1992). The mean and standard deviation (SD) was calculated to represent the variability of the individual values:

$$
\operatorname{Tr} L=1+\left(\sum_{j=1}^{n} D C_{j i}\left(\operatorname{TrL}_{\mathrm{j}}\right)\right)
$$

where: $\mathrm{DC}_{\mathrm{ji}}$ represents the diet composition in weight in terms of prey proportion $(i)$ in the predator's diet $(j)$; TrL represents the trophic level of the prey species $(i)$, 


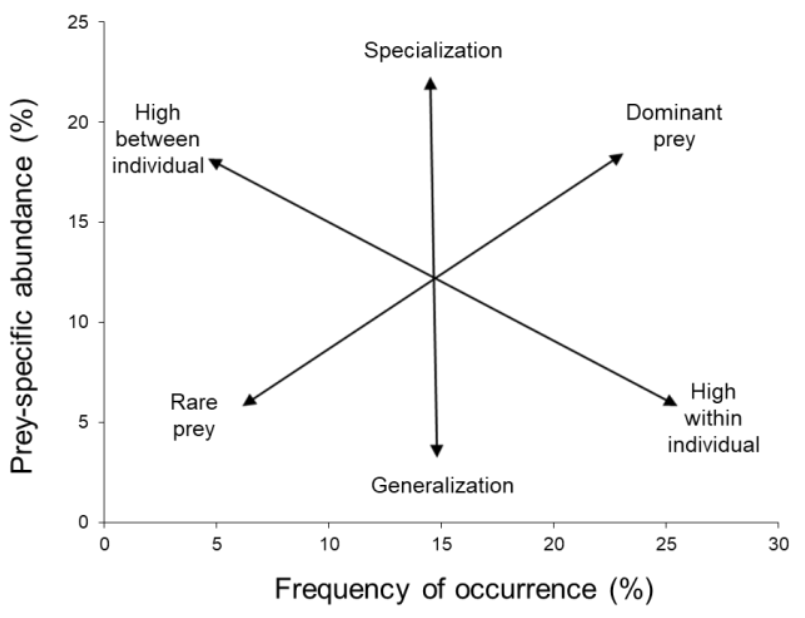

Figure 2. Graphic proposed by Amundsen et al. (1996). The Prey-specific abundance vs. frequency of occurrence (Chipps \& Garvey, 2007).

and $\mathrm{n}$ is the number of prey groups in the diet. Trophic level for the fish prey species was obtained from the Fishbase network (Froese \& Pauly, 2003), while the TrL for cephalopods and crustaceans were obtained as proposed by Cortés (1999).

Trophic overlap was calculated with a nonparametric multivariate analysis of variance permutation (PERMANOVA) through 1000 permutations. This analysis was applied with the Adonis function of the vegan package (Oksanen et al., 2015) in R 3.0.1 (R Core Team, 2013). The probability values $(P)$ generated by R statistic were considered significant when $P$ value was less than or equal to 0.05 . Subsequently, with the PRIMER v.6. Software, a similarity percentage analy-sis (SIMPER), was applied to determine the trophic items responsible for the differences in the diets for each category analyzed. This analysis calculates the average differences between the species and records the contribution of each category to this inequality (Clarke \& Warwick, 1994).

Monthly average sea surface temperature (SST) data from 2015 was used to analyze the possible variations of $R$. terraenovae diet associated with changes in SST. This data was obtained by the NOAA and the NCDC (National Climatic Data Center). SST values located between longitudes 90 and $91^{\circ} \mathrm{W}$, and latitudes 19 and $20^{\circ} \mathrm{N}$ were chosen, because they are the approximate coordinates of the $R$. terraenovae fishing zone. This data was provided by fishermen operating on the coast of San Francisco de Campeche. Also, the diversity of the trophic spectrum of $R$. terraenovae and its changes at a temporal level was determined using the Shannon-Wiener diversity index (Pielou, 1975):

$$
H^{\prime}=\sum_{i=1}^{s} P_{i} \ln P_{i}
$$

where $\mathrm{S}$ is the total number of prey identified; $\mathrm{P}_{i}$, the proportion of each of the prey that constitutes the diet of the predator; and $\mathrm{n}$ is the total number of prey. This index has a range of values from 0 to 6 . Values $<3$ indicate a slightly diverse diet dominated by a few species, while values $>3$ indicate a diet dominated by several species (Alderete-Macal, 2007).

Finally, since the data did not comply with the principles of normality $(\mathrm{W}=0.49, P=0.001)$ and homogeneity of variance $(\mathrm{F}=3.24, P=0.04)$, we used a non-parametric analysis of Spearman's rank correlation (Statistica v.8.0) to determine the relationship between the SST and the diet diversity of $R$. terraenovae on a monthly level.

\section{RESULTS}

Rhizoprionodon terraenovae specimens $\mathrm{n}=124$ were collected during 2015, with a total of 26 females (21.6\%) and 98 males (78.4\%). Total length ranged from 34.5 to $106.0 \mathrm{~cm}$, with an average value of 88.26 $\pm 18.24 \mathrm{~cm}$. The size range for females was $34.5-106.0$ $\mathrm{cm}$ LT with an average of $88.6 \pm 23.1 \mathrm{~cm}$, while the range for males was 44.0-104.0 cm LT with an average of $88.1 \pm 17.2 \mathrm{~cm}$. At the seasonal level, a total of 100 stomachs were collected for the dry season, eight stomachs for the rainy season, and 16 for the winter storm season (Table 1).

Of the total stomachs, 68 contained food (54.84\%), and 56 were empty (45.16\%). Filling percentage analysis indicated that $46 \%$ of the stomachs presented group 1, and the digestive state of the prey species indicated a higher number of preys in group 3 (advanced digestion). The prey species accumulated diversity curve shows that 32 stomachs analyzed were sufficient to describe the diet of $R$. terraenovae, obtaining a coefficient of variation $(\mathrm{CV})$ below 0.05 (Fig. 3). For the other categories (sexes, body size, and climatic seasons), values close to 0.05 were obtained (Table 1).

The general trophic spectrum was composed of a total of 32 identified preys integrated into four groups and seven subgroups: cephalopods (octopods), crustaceans (shrimps, portunids and stomatopods), cartilaginous fish (rays), and teleost fish (demersal and pelagic). Based on \% MN and \%MW the most important preys for $R$. terraenovae were Haemulon plumierii $(\% \mathrm{MN}=22.91 \pm 0.40 ; \% \mathrm{MW}=22.74 \pm 0.40)$ and Sardinella aurita $(\% \mathrm{MN}=14.06 \pm 0.34 ; \% \mathrm{MW}=14.73 \pm$ 0.36). According to $\% \mathrm{MN}$ and $\% \mathrm{MW}$ the most important prey in the dry season were $H$. plumierii $(\% \mathrm{MN}=25.33 \pm 0.42 ; \% \mathrm{MW}=25.1 \pm 0.42)$ and 
Table 1. The total number of stomachs collected by categories for Rhizoprionodon terraenovae. n: number of individuals, TL: total length, SD: standard deviation, SWFC: stomachs with food content, ES: empty stomachs, CV: coefficient of variation.

\begin{tabular}{llcccccc}
\hline Categories & & $\mathrm{n}$ & TL $(\mathrm{cm})$ & SD & SWFC & ES & CV \\
\hline \multirow{2}{*}{ Sex } & Females & 26 & 85.32 & 22.38 & 13 & 13 & 0.054 \\
& Males & 98 & 86.27 & 17.38 & 51 & 47 & 0.049 \\
& Total & 124 & & & 64 & 60 & \\
Body size (cm) & Group 1 $(37-75 \mathrm{~cm})$ & 20 & 57.03 & 14.13 & 13 & 7 & 0.046 \\
& Group 2 $(76-102 \mathrm{~cm})$ & 104 & 94.48 & 6.35 & 51 & 53 & 0.048 \\
& Total & & & & 64 & 60 & \\
& Dry & 100 & 90.31 & 12.12 & 51 & 50 & 0.045 \\
Climatic seasons & Rainy & 8 & 95.85 & 8.12 & 6 & 2 & 0.06 \\
& Winter storm & 16 & 56 & 23.7 & 7 & 8 & 0.044 \\
& Total & 124 & & & 64 & 60 & \\
\hline & & & & & & &
\end{tabular}

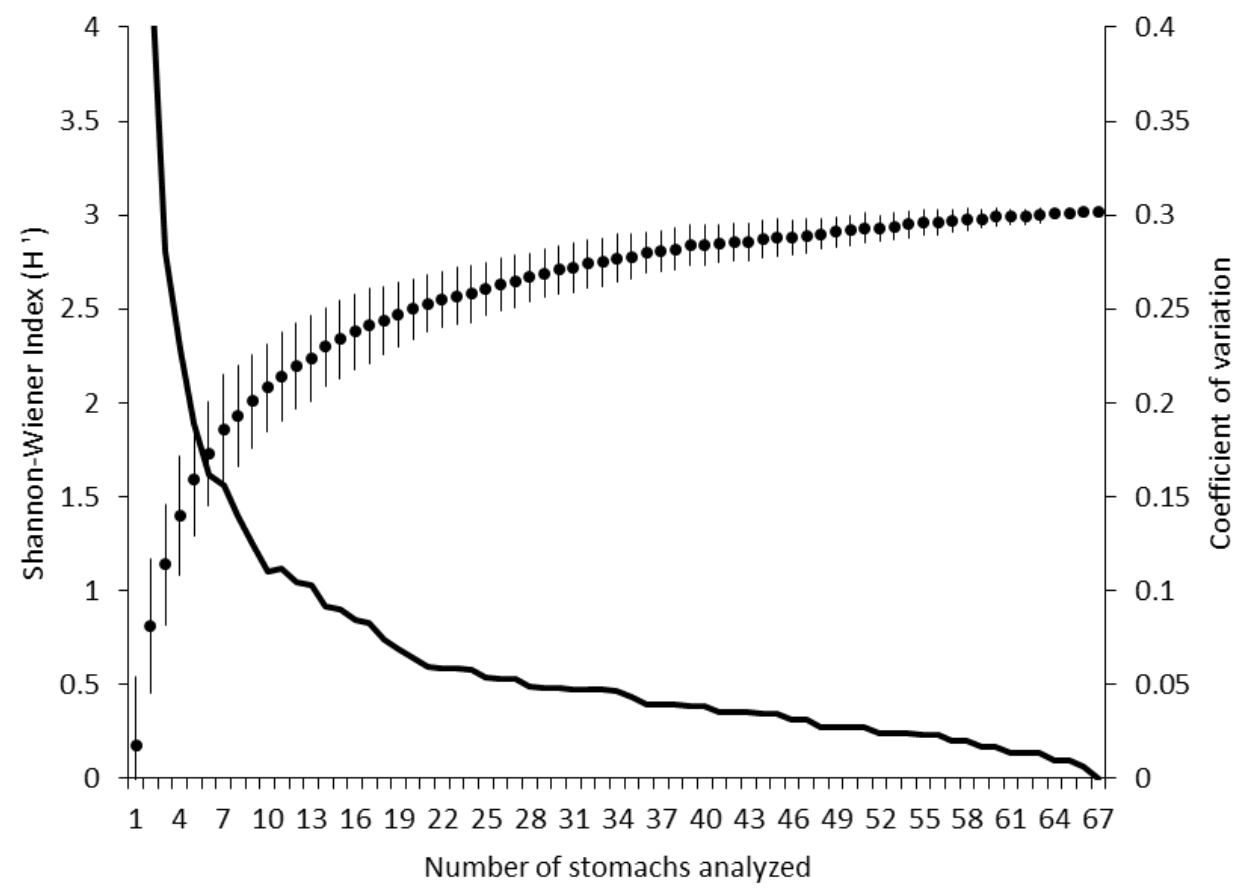

Figure 3. Randomized diversity cumulative curve of prey species generated for Rhizoprionodon terraenovae. ShannonWiener diversity index $=$ black circles, vertical lines $=$ standard deviation, and black line $=$ coefficient of variation .

S. aurita $(\% \mathrm{MN}=16.00 \pm 0.40 ; \% \mathrm{MW}=16.00 \pm 0.37)$. For the rainy season, all preys had the same value $(\% \mathrm{MN}$ and $\% \mathrm{MW}=16.67 \pm 0.40)$. For the winter storm season, the most important preys were Portunus spp., Bairdiella spp., Eucinos-tomus gula, H. plumierii, Caranx spp. and Tylosurus crocodilus, all with a value of $(\% \mathrm{MN}$ and $\% \mathrm{MW}=11.11 \pm 0.33)$ (Table 2$)$.

According to \%PSIRI, the main prey consumed by $R$. terraenovae were $H$. plumierii $(\% \mathrm{PSIRI}=22.82)$, followed by $S$. aurita (\%PSIRI = 12.83). At a temporary level, the main preys consumed according to $\%$ PSIRI in the dry season were $H$. plumierii (\% PSIRI
= 25.22), followed by $S$. aurita (\%PSIRI = 16), Bairdiella ronchus $(\% \mathrm{PSIRI}=7.16)$, and Urobatis jamaicencis $(\%$ PSIRI $=7)$. For the rainy season, all preys presented a value of \%PSIRI $=16.67$. For the winter storm season, the main prey consumed were Bairdiella spp., Caranx spp., E. gula, H. plumierii, Portunus spp. and T. crocodilus $(\%$ PSIRI $=11.11)$, followed by Harengula spp. (\%PSIRI = 7.87) and Clepticus parrae $(\%$ PSIRI = 6.62) $($ Table 2$)$.

Diet breadth $(B i)$ values were less than 0.6 for all categories $(B i=0.002)$, indicating that $R$. terraenovae is a specialized predator. Amundsen graphical analysis 
Table 2. Summary of food categories in the stomachs of Rhizoprionodon terraenovae from the southern Gulf of Mexico expressed as percentages \pm standard deviation of the mean proportion by number $(\% \mathrm{MN})$, mean ratio by weight $(\% \mathrm{MW})$, frequency of occurrence $(\% \mathrm{FO})$, and \%PSIRI for climatic seasons. *Not present in the diet.

\begin{tabular}{|c|c|c|c|c|c|c|c|c|c|c|c|c|c|}
\hline \multirow{2}{*}{ Prey item } & & \multicolumn{4}{|c|}{ Dry } & \multicolumn{4}{|c|}{ Rainy } & \multicolumn{4}{|c|}{ Winter storm } \\
\hline & & $\% \mathrm{MN}$ & $\% \mathrm{MW}$ & $\% \mathrm{FO}$ & \%PSIRI & $\% \mathrm{MN}$ & $\% \mathrm{MW}$ & $\% \mathrm{FO}$ & \%PSIRI & $\% \mathrm{MN}$ & $\% \mathrm{MW}$ & $\% \mathrm{FO}$ & \%PSIRI \\
\hline \multirow[t]{5}{*}{ Batoidea } & Urobatis jamaicencis & $6 \pm 0.2$ & $6 \pm 0.2$ & 6 & 7 & $*$ & $*$ & $*$ & $*$ & $*$ & $*$ & $*$ & $*$ \\
\hline & Squilla empusa & $1 \pm 0.07$ & $1.4 \pm 0.09$ & 2 & 1.17 & $*$ & $*$ & $*$ & $*$ & $*$ & * & $*$ & $*$ \\
\hline & Farfantepenaeus aztecus & $2 \pm 0.14$ & $2 \pm 0.14$ & 2 & 2 & $*$ & $*$ & * & $*$ & $*$ & * & * & $*$ \\
\hline & Callinectes sapidus & $*$ & $*$ & $*$ & $*$ & $*$ & $*$ & $*$ & $*$ & $3.70 \pm 0.11$ & $6.82 \pm 0.20$ & 11.11 & 5.26 \\
\hline & Portunus gibbesii & $1.33 \pm 0.09$ & $1.7 \pm 0.12$ & 2 & 1.51 & $*$ & $*$ & $*$ & $*$ & $3.70 \pm 0.11$ & $2.53 \pm 0.1$ & 11.11 & 3.11 \\
\hline Crustacea & Portunus spp. & $2 \pm 0.14$ & $2 \pm 0.14$ & 2 & 2 & $*$ & $*$ & $*$ & $*$ & $11 \pm 0.33$ & $11 \pm 0.33$ & 11.11 & 11 \\
\hline \multirow[t]{11}{*}{ Cephalopoda } & $\begin{array}{l}\text { Octopus spp. } \\
\text { Demersal fish }\end{array}$ & $6 \pm 0.21$ & $5 \pm 0.20$ & 8 & 5.31 & $*$ & $*$ & $*$ & $*$ & $3.70 \pm 0.11$ & $1.75 \pm 0.05$ & 11.11 & 2.75 \\
\hline & Archosargus spp. & $1 \pm 0.07$ & $0.64 \pm 0$ & 2 & 0.83 & $*$ & $*$ & $*$ & $*$ & $*$ & $*$ & $*$ & $*$ \\
\hline & Bairdiella ronchus & $7 \pm 0.25$ & $7.33 \pm 0.25$ & 8 & 7.20 & $*$ & $*$ & $*$ & $*$ & $*$ & * & $*$ & $*$ \\
\hline & Bairdiella spp. & * & $*$ & $*$ & $*$ & $*$ & * & $*$ & $*$ & $11 \pm 0.33$ & $11 \pm 0.33$ & 11.11 & 11 \\
\hline & Centropomus undecimalis & $*$ & $*$ & $*$ & $*$ & $16.67 \pm 0.40$ & $16.67 \pm 0.40$ & 16.67 & 16.67 & $*$ & $*$ & $*$ & $*$ \\
\hline & Clepticus parrae & $*$ & $*$ & $*$ & $*$ & $*$ & $*$ & $*$ & $*$ & $5.56 \pm 0.17$ & $7.69 \pm 0.23$ & 11.11 & 6.62 \\
\hline & Eucinostomus gula & $2 \pm 0.14$ & $4 \pm 0.19$ & 4 & 3 & $16.67 \pm 0.40$ & $16.67 \pm 0.40$ & 16.67 & 16.67 & $11 \pm 0.3$ & $11 \pm 0.3$ & 11.11 & 11 \\
\hline & Gunterichthys longipenis & $*$ & $*$ & $*$ & $*$ & $*$ & $*$ & $*$ & $*$ & $5.56 \pm 0.17$ & $3.45 \pm 0.10$ & 11.11 & 4.50 \\
\hline & Haemulon plumierii & $25 \pm 0.42$ & $25.10 \pm 0.42$ & 28 & 25 & $16.67 \pm 0.40$ & $16.67 \pm 0.40$ & 16.67 & 16.67 & $11 \pm 0.33$ & $11 \pm 0.33$ & 11.11 & 11 \\
\hline & Lutjanus synagris & $0.67 \pm 0.42$ & $0.57 \pm 0$ & 2 & 0.61 & $*$ & $*$ & $*$ & $*$ & $*$ & $*$ & $*$ & $*$ \\
\hline & Micropogonias undulatus & $2 \pm 0.14$ & $2 \pm 0.14$ & 2 & 2 & $*$ & * & * & $*$ & $*$ & * & $*$ & $*$ \\
\hline \multirow[t]{16}{*}{ Teleostei } & Orthopristis chrysoptera & $0.67 \pm 0$ & $0.67 \pm 0$ & 2 & 0.67 & $*$ & $*$ & $*$ & $*$ & $*$ & $*$ & $*$ & $*$ \\
\hline & Sphoeroides spengleri & $5 \pm 0.2$ & $5.47 \pm 0.22$ & 6 & 5.25 & $*$ & $*$ & $*$ & $*$ & $*$ & $*$ & $*$ & $*$ \\
\hline & Stephanolepis hispidus & $3 \pm 0.1$ & $2.52 \pm 0.14$ & 4 & 2.59 & $*$ & $*$ & $*$ & $*$ & * & * & * & $*$ \\
\hline & $\begin{array}{l}\text { Trachinotus carolinus } \\
\text { Pelagic fish }\end{array}$ & $1 \pm 0$ & $0.60 \pm 0$ & 2 & 0.60 & $*$ & $*$ & $*$ & $*$ & $*$ & $*$ & $*$ & $*$ \\
\hline & Brevoortia gunteri & $2 \pm 0.07$ & $1.6 \pm 0.06$ & 6 & 1.70 & $16.67 \pm 0.40$ & $16.67 \pm 0.40$ & 16.67 & 16.67 & $5.56 \pm 0.17$ & $0.90 \pm 0$ & 11.11 & 3.23 \\
\hline & Caranx latus & $2 \pm 0.14$ & $2 \pm 0.14$ & 2 & 2 & $*$ & $*$ & $*$ & $*$ & * & $*$ & $*$ & $*$ \\
\hline & Caranx spp. & $2 \pm 0.14$ & $2 \pm 0.14$ & 2 & 2 & $*$ & $*$ & $*$ & $*$ & $11 \pm 0.33$ & $11 \pm 0.33$ & 11.11 & 11 \\
\hline & Harengula clupeola & $1 \pm 0$ & $0.10 \pm 0$ & 2 & 0.30 & $16.67 \pm 0.40$ & $16.67 \pm 0.40$ & 16.67 & 16.67 & $*$ & * & $*$ & $*$ \\
\hline & Harengula spp. & $*$ & $*$ & $*$ & $*$ & $16.67 \pm 0.40$ & $16.67 \pm 0.40$ & 16.67 & 16.67 & $5.56 \pm 0.17$ & $10.20 \pm 0.30$ & 11.11 & 7.87 \\
\hline & Hemiramphus brasiliensis & $1 \pm 0.07$ & $1.1 \pm 0.08$ & 2 & 1.07 & $*$ & $*$ & $*$ & $*$ & * & $*$ & $*$ & $*$ \\
\hline & Lachnolaimus maximus & $4 \pm 0.19$ & $4 \pm 0.19$ & 4 & 4 & $*$ & $*$ & $*$ & $*$ & $*$ & $*$ & $*$ & $*$ \\
\hline & Opisthonema oglinum & $1 \pm 0$ & $1.4 \pm 0.10$ & 2 & 1.05 & $*$ & $*$ & $*$ & $*$ & $*$ & $*$ & $*$ & $*$ \\
\hline & Sardinella aurita & $16 \pm 0.4$ & $16 \pm 0.37$ & 16 & 16 & $*$ & $*$ & $*$ & $*$ & $*$ & $*$ & $*$ & $*$ \\
\hline & Tylosurus crocodilus & $1 \pm 0.07$ & $0.85 \pm 0.06$ & 2 & 0.92 & $*$ & $*$ & $*$ & $*$ & $11 \pm 0.33$ & $11 \pm 0.33$ & 11.11 & 11 \\
\hline & Unidentified teleosts & $4 \pm 0.19$ & $4 \pm 0.19$ & 4 & 4 & $*$ & $*$ & $*$ & $*$ & $*$ & $*$ & $*$ & $*$ \\
\hline & Total & 100 & 100 & & 100 & 100 & 100 & & 100 & 100 & 100 & & 100 \\
\hline
\end{tabular}

suggests that $R$. terraenovae is a specialist consumer in general, with a specialization observed for $H$. plumierii. Specialization was also seen for $H$. plumierii between sexes: males favored $H$. plumierii, while females favored pelagic fish (H. clupeola and B. gunteri). When comparing body size, sharks in group 3 presented specialization for a single type of prey (H. plumierii). In contrast, sharks in group 2 showed a mixed feeding strategy, with some individuals showing a specialized diet, and others a more generalized feeding strategy. When comparing climatic seasons, $H$. plumierii was the dominant prey during the dry season, $B$. gunteri during the rainy season, and a more generalized diet during the winter storm season (Fig. 4).

The Shannon-Wiener diversity index generated a value of $H^{\prime}=2.76$ for trophic diversity, suggesting an intermediate diversity of prey for this predator. While the calculated trophic level was $4.2 \pm 0.4$, placing $R$. terraenovae as a third level carnivore (Table 3 ).

Comparison of prey species according to PERMANOVA indicated a statistically significant trophic differences between sexes $(\mathrm{F}=32.22 ; P<0.05)$, body size $(\mathrm{F}=13.68 ; P<0.05)$ and among climatic seasons $(\mathrm{F}=23.86 ; P<0.05)$.

According to SIMPER analysis, the trophic components that contributed to this dissimilarity at the sex level were $H$. plumierii (14.7\%) for males, and $S$. aurita $(10.9 \%)$ and B. gunteri (7.9\%) for females. The dissimilarity between body size was Sphoeroides spengleri (10.2\%) and Portunus gibbesii (6.1\%) for sharks of group 1, while $H$. plumierii $(10.2 \%)$ for sharks of group 2, which were the main prey that presented a greater average abundance between body size. The high dissimilarity observed between winter storm and dry season (average dissimilarity $=95.4 \%$ ), while comparison between dry vs. rain (average dissimilarity $=94.5 \%$ ) and winter storm $v s$. rainy (average dissimilarity $=93.8 \%$ ) yielded very low values. The trophic components that contributed to this dissimilarity in climatic seasons (winter storm $v s$. dry) were $S$. aurita $(7.2 \%)$ and B. ronchus $(3.3 \%)$ for the dry season. Clepticus parrae (3.6\%) and Gunterichthys 


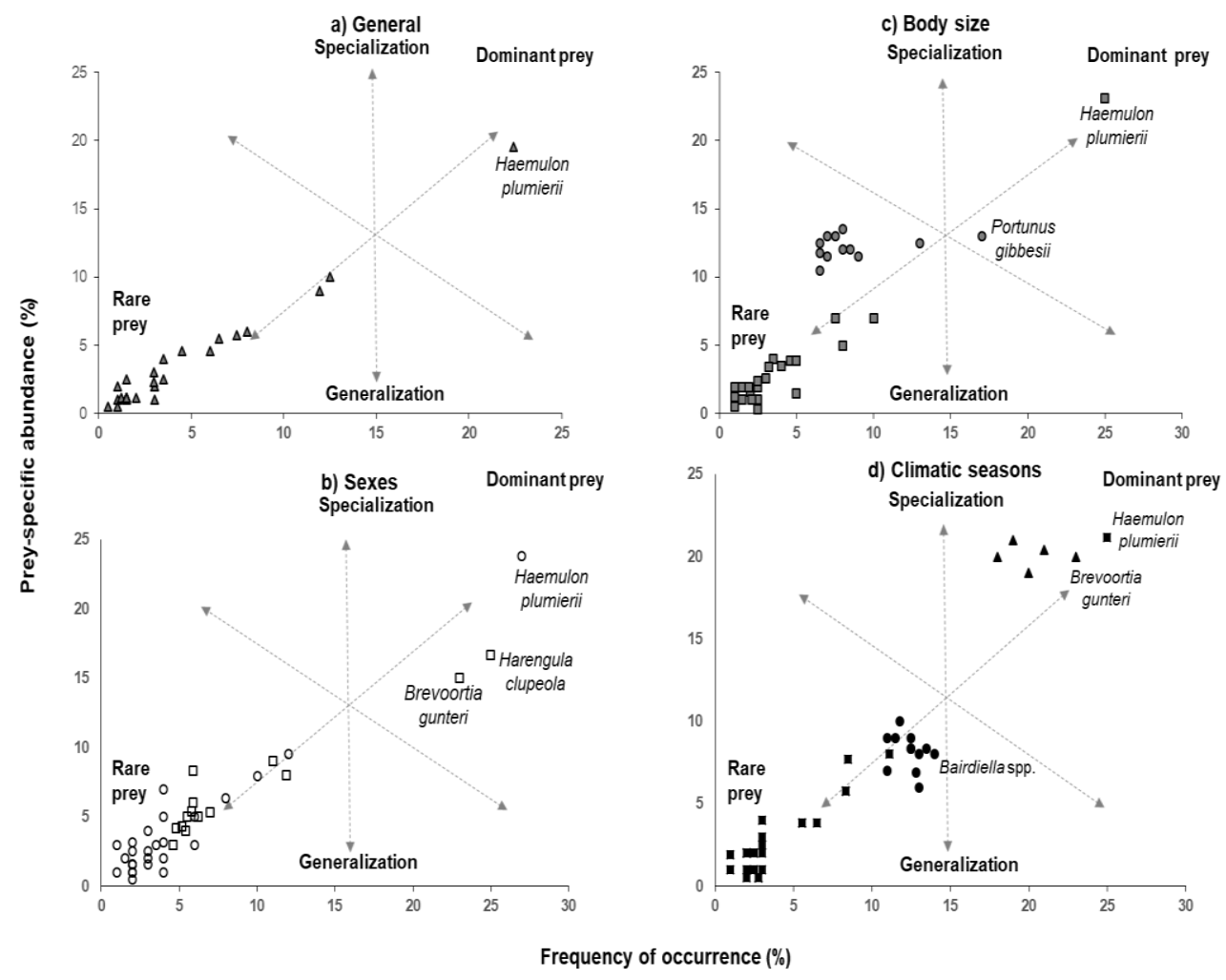

Figure 4. a) General food strategy of Rhizoprionodon terraenovae. Gray triangle: prey consumed by $R$. terraenovae, b) sexes specialization. White circle: males, white square: females, c) body size specialization. Gray circle: group 1, gray square: group 2, d) climatic seasons specialization. Black square: dry, black triangle: rainy, black circle: winter storm.

Table 3. Diet amplitude values (Levin index), diversity values of prey consumed (Shannon-Wiener index), and trophic level values (Christensen \& Pauly, 1992) by categories for Rhizoprionodon terraenovae. SD: standard deviation.

\begin{tabular}{llccc}
\hline \multirow{2}{*}{ Categorie } & & $\begin{array}{c}\text { Levins index } \\
(\mathrm{Bi})\end{array}$ & $\begin{array}{c}\text { Diversity index } \\
\left(\mathrm{H}^{\prime}\right)\end{array}$ & Mean $\pm \mathrm{SD}$ \\
\hline \multirow{2}{*}{$\mathrm{Sex}$} & Females & 0.0062 & 2.25 & $4.2 \pm 0.4$ \\
& Males & 0.0035 & 2.67 & $4.3 \pm 0.4$ \\
\hline \multirow{2}{*}{ Body size $(\mathrm{cm})$} & Group 1 $(37-75 \mathrm{~cm})$ & 0.0078 & 2.20 & $4.2 \pm 0.4$ \\
& Group 2 $(76-102 \mathrm{~cm})$ & 0.0038 & 2.65 & $4.3 \pm 0.3$ \\
\hline \multirow{2}{*}{ Climatic seasons } & Dry & 0.0046 & 1.76 & $4.2 \pm 0.2$ \\
& Rainy & 0.0625 & 1.61 & $4.3 \pm 0.4$ \\
& Winter storm & 0.00424 & 1.69 & $4.1 \pm 0.3$ \\
\hline
\end{tabular}

longipenis $(3.6 \%)$ for the winter storm season, which was the main prey that showed a higher average abundance between climatic seasons.

According to the monthly values of the SST for the fishing zone, the lowest temperatures were recorded during the dry season (January and February), while the highest temperatures were recorded during the rainy season (July and August). We also observed that the dry season presented the highest diversity values of prey consumed. Finally, according to Spearman's correlation analysis, we found a negative correlation between the diversity of the prey consumed and the sea surface temperature (Table 4).

\section{DISCUSSION}

Of the stomachs analyzed, a relatively high number of empty stomachs were found (45.16\% of total stomachs), while those that presented food, exhibited a filling percentage of categories 1 and 2 (approximately 75\% of filling). Similar results have been reported for other species such as Rhizoprionodon longurio (Alatorre- 
Table 4. Diversity monthly values of prey consumed (Shannon-Wiener index), SST: sea surface temperature values, and Spearman correlation value and $P$-value $(P<$ $0.05)$.

\begin{tabular}{lcccc}
\hline Month & $\begin{array}{c}\text { Diversity index } \\
\left(H^{\prime}\right)\end{array}$ & $\begin{array}{c}\text { SST } \\
\left({ }^{\circ} \mathrm{C}\right)\end{array}$ & $\begin{array}{c}\text { Spearman } \\
\text { value }\end{array}$ & $P$-value \\
\hline January & 1.61 & 24.4 & & \\
February & 2.52 & 23.9 & & \\
March & 2.07 & 26.5 & -0.753 & 0.05 \\
May & 0.69 & 28.7 & & \\
July & 1.61 & 28.5 & & \\
November & 1.77 & 28.0 & & \\
\hline
\end{tabular}

Ramírez et al., 2013), where a high number of empty stomachs and a large number of stomachs were included in category $1 \quad(<25 \%$ filled stomach). Ovchinnikov (1970) mentions that the variation in the percentage of filling is related to the feeding schedule. According to Driggers et al. (2012), feeding of some Carcharhinidae species is associated with periods of low light, suggesting that these species of predators could be more physically active during the night.

Most of the stomachs presented prey in an advanced state of digestion (3 and 4). The degree of digestion has been reported to be directly related to the taxonomic group. For example, for bony fish, duration in the stomach is approximately $24 \mathrm{~h}$ (Tricas, 1979), while cephalopods are between 5 to $10 \mathrm{~h}$ (Olson \& Boggs, 1986). In this study, the advanced state of digestion of prey species could be related to the fishing time in Campeche, as explained below.

In San Francisco de Campeche, gillnets are authorized as fishing equipment for shark capture (DOF, 2015). Fishing lasts between 10 and $12 \mathrm{~h}$ and is usually done during the night, coinciding with AlatorreRamírez et al. (2013), where they suggest that highly digested preys are indicative of high feeding activity at dusk. Similarly, Barry (2002) reports that during the dusk, the capture of Rhizoprionodon terraenovae increases. Therefore, the high number of empty stomachs, the low percentage of filling, and the digestion degree of prey consumed exceed 10 hours.

Preti et al. (2001) suggest that $R$. terraenovae is a predator being captured off the coast of Campeche, in potential feeding areas, during its displacement to feed during the night (e.g., Los Petenes), coinciding with Klimley (1983), where S. lewini in large daytime aggregations were observed at the seamounts of the Gulf of California. These sites can serve refuge points in the center of the feeding routes. During the day, sharks swim slowly over the underwater mound without foraging, leaving at dusk to feed in the pelagic environment.
In this study, the diet of $R$. terraenovae was found to be mainly composed of teleost fish, coinciding with observations by authors for the northern region of the Gulf of Mexico (Gelsleichter et al., 1999; Barry, 2002; Hoffmayer \& Parsons, 2003; Bethea et al., 2006), and the southern area of the Gulf of Mexico (AvendañoÁlvarez et al., 2013; García, 2014). These similarities are probably due to its distribution area and displacement in the water column, coinciding with a reported by García (2014) for the same region. Additionally, other species of the same genus ( $R$. longurio) in the Mexican Pacific present a diet mainly composed of teleost fish, crustaceans, mollusks, and elasmobranchs (Alatorre-Ramírez, 2003; AldereteMacal, 2007). Therefore, R. terraenovae could be considered an ichthyophagous predator. This specific characteristic is represented by prey species of various habitats (for example, demersal, pelagic, and benthic), implying that $R$. terraenovae probably makes vertical migrations in the water column, coinciding with Parsons \& Hoffmayer (2005). They mention this species presenting a bento-pelagic habitat. For this reason, $R$. terraenovae, although consuming prey species from different habitats, feeds with more frequency in a more coastal habitat since Haemulon plumierii was the most important prey according to $\%$ PSIRI.

Levin's index (Krebs, 1999) $(<0.6)$ and Costello (1990) graphs (population type c) indicate that $R$. terraenovae is a specialist predator. This feeding strategy is due to specialization in a single type of prey, and mainly bony fish, with $\mathrm{H}$. plumierii being the most prominent prey consumed with occasional consumption of secondary prey, an abundant and available species throughout the fishing during the year (AyalaPérez et al., 2015). However, Shannon-Wiener index indicated values of an intermediate diversity due to a high richness of species consumed (characteristic of a generalist predator). A combination of both indices would explain the trophic behavior of $R$. terraenovae feeding on the resource that is most abundant in the area. Additionally, Alatorre-Ramírez et al. (2013) suggested $R$. longurio as a specialist-opportunistic predator due to its feeding on fish that form large banks.

According to the Costello graphs, $R$. terraenovae presented a specialization strategy for a type of prey $(H$. plumierii) during the dry season and rainy season (Brevoortia gunteri). However, R. terraenovae presented a generalization strategy in the consumption of prey during the winter storm season.

Changes in dominant species within the diet of $R$. terraenovae throughout the years (Hoffmayer \& Parsons, 2003) and in different areas (Bethea et al., 2006), allow us to concluded that this shark is an 
opportunistic predator rather than a specialist, feeding on more abundantly available species in the area. This type of behavior can be an advantage for $R$. terraenovae since fish with an overly selective diet tend to be more susceptible to changes in the availability of prey in the ecosystem (Trowbridge, 1991; Conde-Moreno, 2009).

PERMANOVA indicated significant differences in the three categories (sexes, body size, and climatic seasons). According to SIMPER, at the sex level, the trophic spectrum for females was composed of pelagic fish, with $B$. gunteri being the most important (\%PSIRI). Trophic spectrum for males was composed of demersal fish, with $H$. plumierii as the most important (\%PSIRI), which coincides with García (2014), who reports differences in the diet of $R$. terraenovae between sexes. However, this author indicates that females consumed demersal fish (Nicholsina usta), and males consumed pelagic fish belonging to the Clupeidae family. Several authors report that in sharks, there are differences in the trophic spectrum between sexes (Cortés \& Gruber, 1990; Ellis, 2003; Bethea et al., 2006). Differences may be due to sexual segregation, with females and males having access to different habitats, as well as to different prey (Springer, 1967; Wetherbee \& Cortés, 2004). Females are consuming more pelagic fishes by feeding in a more oceanic area while males consume mostly demersal fishes feeding closer to the coastal zone; this is a signal of sexual segregation. This was observed in the present study and coincidentally with Parsons \& Hoffmayer (2005); they describe that $R$. terraenovae as a species with geographical segregation between sexes.

At body size level, sharks in group 1 fed on Sardinella aurita and Octopus spp., while sharks in group 2 fed on $H$. plumierii. These results coincide with García (2014), who reports that juveniles of $R$. terraenovae consumed pelagic fish, while adults consumed demersal fish. Previous studies have reported changes in diet depending on the maturity stage (Klimley, 1983; Galvan-Magaña et al., 1989). Lowe et al. (1996) noted a change in diet with growth in Galeocerdo cuvier (Péron \& Lesueur, 1822) due to several factors: a) larger sharks may feed on large prey because they have access to different habitats, b) sharks at different stages of development occupy different areas and are segregated by size and sex, and c) as shark size increases, the prey capture efficiency increases, as the senses are fully developed, and sharks can capture larger and faster prey. Wetherbee et al. (1990), mentions that the factors that affect food preferences of sharks are: ontogenetic states and prey size. Lowe et al. (1996) indicate a change in the shark's diet during ontogeny, as in most fish. Several authors have reported on the ontogenic variation of the shark's diet (Brickle $e t$ al., 2003; Bethea et al., 2006; Vögler et al., 2009), with a greater tendency to ingest larger and more mobile prey with the increase in the size of the predator (Navia et al., 2007). Therefore, in the present study, trophic segregation was observed at the body size level, where group 1 sharks most likely fed in pelagic habitats, while group 2 sharks fed in coastal habitats, probably related to reproductive aspects (Pérez-Jiménez \& MéndezLoeza, 2015).

Since each observed group presents diet shifts, it was necessary to evaluate TrL. However, no difference was observed between categories. Thus, $R$. terraenovae function could be considered similar. Most sharks are apex predators that occupy high-level trophic positions (Cortés, 1999). The calculated TrL for $R$. terraenovae in this study was 4.2. These results coincide with Cortés (1999), who estimated a TrL of 4.0 for $R$. terraenovae, and Drymon et al. (2012), who reported a TrL of 4.4 to 4.6 for $R$. terraenovae, based on stable isotope analysis. Therefore, this predator was considered a tertiary carnivore. Similarly, for $R$. longurio, Conde-Moreno (2009), using the same methodology, reported a TrL of 4.2. Additionally, Treloar et al. (2007) suggest that organisms mostly feeding on bony fish present a TrL > 4.0, similar to that of such as $R$. terraenovae.

Several studies indicate great ecological importance of large shark species in marine ecosystems (Myers et al., 2007; Heithaus et al., 2008) and according to current studies on the diet of various shark species, small sharks are described as mesopredators (Myers et $a l ., 2007)$ as is the case of $R$. terraenovae. However, currently, there is very little published information on the importance of mesopredators (such as sharks) within the marine community.

These results indicate that $R$. terraenovae is considered a mesopredator, which is defined as any predator that is in the intermediate trophic levels, regardless of its size or taxonomy, capable of transmitting the effects of the trophic levels higher than the lower levels through the energy flow. They also fulfill an essential ecological function when large predators have been eliminated from different ecosystems (Navia-López, 2013). It is important to know that these organisms are at risk only by apex predators (Heithaus et al., 2008; Vaudo \& Heithaus, 2009).

Predator TrL information is very important since energy flows can be calculated within the trophic network of the marine community. According to the results obtained in the present study, $R$. terraenovae performs a critical trophic functional role in the dynamics of the marine ecosystem, since it can be considered top predators in the Campeche coast, as a possible structural enhancer of the prey populations in the ecosystem. 
It is necessary to identify possible negative impacts on the ecosystem, not just at an ecological level, but also at a social level. Therefore, there is a need to monitor and conserve this key species. Heithaus et al. (2008) reported that as large shark catches increase, a decrease in Carcharhinus limbatus abundances was observed, and the abundance of Rhinoptera bonasus rays began to increase, causing eventual declines in catches of various species of bivalves with commercial importance in the bay of North Carolina. However, changes in the abundance of species are not the only consequence of the elimination of the main predators, since habitats can also be altered (Myers et al., 2007). Pauly (1998) suggests that the high trophic positions of sharks mean that the overall performance of fisheries should be low and not sustainable at high levels of exploitation. Therefore, since $R$. terraenovae presents a high interaction with abundant prey species (e.g., $H$. plumierii) of the region, its exclusion could generate reactions such as those found in the works mentioned above.

SST during 2015 in Campeche coast, ranged between 23 to $29^{\circ} \mathrm{C}$, with the coldest temperatures in February, and the hottest in August. Elasmobranchs are characterized as migratory species (Brenes et al., 2000). In this study, $R$. terraenovae presented temporary behavior on the Campeche coast. Most of the organisms were caught in February $\left(23.4^{\circ} \mathrm{C}\right)$. During the warm months $\left(28-29^{\circ} \mathrm{C}\right)$, we observed a decrease in the number of samples collected, coinciding with Kotas et al. (2000) who related the CPUE of Prionace glauca with the SST finding of the greatest catches (21.9 at $21.1^{\circ} \mathrm{C}$ ); while the lowest catches were obtained at high temperatures $\left(26^{\circ} \mathrm{C}\right)$. In the southern Gulf of Mexico, shark-directed fishing is restricted to a few months of activity due to catch seasonality, dependent mainly on changes in the abundance of species due to seasonal movements (Pérez-Jiménez \& Méndez-Loeza, 2015).

In the Gulf of California, $R$. longurio presents a similar behavior. This shark is found along the coasts of Sinaloa and Sonora during winter (January, February) and early spring (March, April, and May) (Márquez-Farías et al., 2005), being the cold months where greater abundance is reported, while in the summer months they migrate to deep water (AlatorreRamírez et al., 2013). Therefore, we can see that changes in temperature influences the structural changes of a community and also the distribution of certain species, possibly accompanied in parallel with changes in diet (Cortés et al., 1996). When the monthly trophic spectrum was analyzed, we observe that when SST dropped cephalopods (Octopus spp.), portunids (Callinectes sapidus, Portunus spp. and P. gibbesii) and some teleost fish (Caranx spp., C. latus and
Tylosurus crocodilus) appeared only in the winter storm season and early dry season (January $=24.4^{\circ} \mathrm{C}$ and February $=23.9^{\circ} \mathrm{C}$ ), respectively. The above is related to the decrease in SST during the winter storm season, due to temporary changes ("nortes") in the area (Yáñez-Arancibia \& Day, 1982) characterized by the influence of frontal systems of polar origin and strong winds with some precipitation from the northeast (Herrera-Silveira, 2010; Tapia-González et al., 2008). It would indicate that these species present low tolerance for temperature changes. Still, their highest abundance occurs in cold waters, such as in the case of portunid crabs (Longhurst, 1967) or cephalopods (Nevárez-Martínez et al., 2010).

Some prey species were also found only during March $\left(26.5^{\circ} \mathrm{C}\right)$, such as Lutjanus synagris (subtropical, $26^{\circ} \mathrm{C}$, Cheung et al., 2013), Micropogonias undulatus (subtropical, $25^{\circ} \mathrm{C}$, Cheung et al., 2013) and T. crocodilus (subtropical, $23^{\circ} \mathrm{C}$, Cheung et al., 2013), and in July $\left(28.5^{\circ} \mathrm{C}\right)$, Centropomus undecimalis (tropical, $25-31^{\circ} \mathrm{C}$, Bussing, 1998). Finally, in November $\left(28^{\circ} \mathrm{C}\right)$ only Clepticus parrae (tropical, 23$27^{\circ} \mathrm{C}$, Cervigón, 1993) and Gunterichthys longipenis (subtropical, 23.3-26. $8^{\circ} \mathrm{C}$, Kaschner et al., 2016) were found.

Other authors have already reported on this type of variation and suggested that the increase in SST has a direct effect, such as the displacement of the geographic boundaries of many species of marine organisms (Southward \& Boalch, 1994; Southward et al., 1995). In this study, we observe that variation found in the prey abundance is due to their movement to different areas as a result of variations in water temperature and changes in the availability of prey.

According to Spearman's correlation, a decrease in prey diversity for $R$. terraenovae was observed with SST increase. Therefore, these temperatures at an extreme level could cause adverse effects on prey species with low tolerance to high temperatures. For this reason, the evaluation of the possible impacts of temporary changes related to the feeding behavior of some species of predators (including sharks) is critical, since SST has a functional role in the ecosystem and influencing the feeding strategy of $R$. terraenovae. In conclusion, on the coast of Campeche, $R$. terraenovae, although a specialized tertiary carnivore, presented diet changes when compared between climatic seasons, do to it feeding on prey with greater availability concerning the SST. This information is important to consider diet shifts related to climate variability, allowing for the design management responses to climate or fisheries threats. 


\section{ACKNOWLEDGMENTS}

JEVM thanks to: Consejo Nacional de Ciencia y Tecnología (CONACyT) and Programa de Becas para Estudios de Posgrado for the scholarship granted with ID number 856590. YETR thanks to: Programa para el Desarrollo Profesional Docente (PRODEP), for financial support to the project "Variación temporal y hábitos alimenticios del cazón Rhizoprionodon terraenovae en las costas de Campeche, México" DSA/103.5/15/2017. Also thanks to Cesar Romero for the field support in the "Reserva de la Biosfera Los Petenes (CONANP) and to Fernando Arenas González for language revision and correction.

\section{REFERENCES}

Alatorre-Ramírez, V.G. 2003. Análisis del contenido alimenticio del tiburón Rhizoprionodon longurio en Mazatlán, México. Tesis de Bachiller en Ciencias, Universidad Autónoma de Sinaloa, Mazatlán, 33 pp.

Alatorre-Ramírez, V.G., Galván-Magaña, F. \& TorresRojas, Y.E. 2013. Trophic habitat of the Pacific sharpnose shark, Rhizoprionodon longurio, in the Mexican Pacific. Journal of the Marine Biological Association of the United Kingdom, 93(8): 22172224. doi: $10.1017 /$ S0025315413000957.

Alderete-Macal, M.J. 2007. Hábitos alimenticios del tiburón horma, Rhizoprionodon longurio (Jordan y Gilbert, 1882) en Salina Cruz, Oaxaca. Tesis de Bachiller en Ciencias, Universidad Autónoma de Baja California Sur, La Paz, 59 pp.

Amundsen, P.A., Gabler, H.M. \& Stalduick, F.J. 1996. A new approach to graphical analysis of feeding strategy from stomach contents data modification of the Costello (1990) method. Journal of Fish Biology, 48: 607-614.

Avendaño-Álvarez, J.O., Pérez-España, H., SalasMonreal, D. \& García-Rodríguez, E. 2013. Captures and diet of three sharks species in the Veracruz Reef System. Open Journal of Marine Science, 3: 66-73.

Ayala-Pérez, L.A., Ramos-Miranda, J., Flores-Hernández, D., Sosa-López, A. \& Martínez-Romero G.E. 2015. Ictiofauna marina y costera de Campeche. Universidad Autónoma de Campeche, Universidad Autónoma MetropolitanaXochimilco. Instituto EPOMEX, Campeche.

Barry, K.P. 2002. Feeding habits of blacktip sharks, Carcharhinus limbatus, and Atlantic sharpnose sharks, Rhizoprionodon terraenovae, in Louisiana coastal waters. M.Sc. Thesis, Louisiana State University, Baton Rouge.

Begon, M., Harper, J.L. \& Townsend, C.R. 1995. Ecología: individuos, poblaciones y comunidades. Ediciones Omega, Barcelona.
Bethea, D., Carlson, J.K., Buckel, J.A. \& Satterwhite, M. 2006. Ontogenetic and site-related trends in the diet of the Atlantic sharpnose shark Rhizoprionodon terraenovae from the northeast Gulf of Mexico. Bulletin of Marine Science, 78(2): 287-307.

Brenes, C.L., Hernández, A. \& Campos, J. 2000. Distribución espacial de capturas de tiburón en el Pacífico nicaragüense y su relación con algunas variables oceanográficas. Revista de Biología Tropical, 48(2-3): 399-411.

Brewer, D.T. \& Warburton, K. 1992. Selection of prey from a seagrass/mangrove environment by golden lined whiting, Sillago analis (Whitley). Journal of Fish Biology, 40: 257-271.

Brickle, P., Laptikhovsky, V., Pompert, J. \& Bishop, A. 2003. Ontogenetic changes in the feeding habits and dietary overlap between three abundant rajid species on the Falkland Islands' shelf. Journal of the Marine Biological Association of the United Kingdom, 86: 1119-1125.

Brown, S.C., Bizzarro, J.J., Cailliet, G.M. \& Ebert, D.A. 2012. Breaking with tradition: redefining measures for diet description with a case study of the Aleutian skate Bathyraja aleutica (Gilbert 1896). Environmental Biology of Fishes, 95(1): 3-20.

Bussing, W.A. 1998. Freshwater fishes of Costa Rica. Editorial de la Universidad de Costa Rica, San José.

Carpenter, K. 2002. The living marine resources of the western central Atlantic. FAO species identification guide for fishery purposes. FAO, Rome.

Carrier, J.C., Musick, J.A. \& Heithaus, M.R. 2010. Sharks and their relatives II, biodiversity, adaptive physiology, and conservation. CRC Press, Boca Raton.

Carrier, J.C., Pratt Jr., H.L. \& Castro, J.I. 2004. Reproductive biology of elasmobranchs. In: Carrier, J.C., Musick, J.A. \& Heithaus, M.R. (Eds.). Biology of sharks and their relatives. CRC Press, Boca Raton, pp. 269-286.

Cervigón, F. 1993. Los peces marinos de Venezuela. Fundación Científica Los Roques, Caracas.

Cheung, W., Watson, R. \& Pauly, D. 2013. Signature of ocean warming in global fisheries catch. Nature, 497: 365-368. doi: 10.1038/nature12156

Chipps, S.R. \& Garvey, J.E. 2007. Assessment of food habits and feeding patterns. In: Guy, C.S. \& Brown, M.L. (Eds.). Analysis and interpretation of freshwater fisheries data. American Fisheries Society, Bethesda, pp. 473-514.

Christensen, V. \& Pauly, D. 1992. ECOPATH II software for balancing steady-state ecosystem models 
and calculating network characteristics. Ecological Modelling, 61: 169-185.

Clarke, M.R. 1986. A handbook for the identification of cephalopod beaks. Clarendon Press, Oxford.

Clarke, K.R. \& Warwick, R.M. 1994. Similarity-based testing for community pattern: the 2-way layout with no replication. Marine Biology, 118: 167-176.

Colwell, R.K. 2006. EstimateS: statistical estimation of species richness and shared species from samples. Version 8. [http://purl.oclc.org/estimates]. Reviewed: July 12, 2019.

Compagno, L., Dando, M. \& Fowler, S. 2006. Guía de campo de los tiburones del mundo. Omega, Barcelona.

Comisión Nacional de Áreas Naturales Protegidas (CONANP). 2006. Programa de conservación y manejo de la Reserva de la Biosfera de Los Petenes. CONANP, Quintana Roo.

Conde-Moreno, M. 2009. Ecología trófica del tiburón bironche, Rhizoprionodon longurio (Jordan \& Gilbert, 1882), en dos áreas del Pacífico Mexicano. Tesis de Maestría, Centro Interdisciplinario de Ciencias Marinas, La Paz, 80 pp.

Cortés, E. 1999. Standardized diet compositions and trophic levels of sharks. ICES Journal of Marine Science, 56: 707-717.

Cortés, E. \& Gruber, S.H. 1990. Diet, feeding habits and estimates of daily ration of young lemon sharks, Negaprion brevirostris (Poey). Copeia, 1990(1): 204218.

Cortés, E., Manire, C.A. \& Hueter, R.E. 1996. Diet, feeding habits, and diel feeding chronology of the bonnethead shark, Sphyrna tiburo, in southwest Florida. Bulletin of Marine Science, 58: 353-367.

Costello, M.J. 1990. Predator feeding strategy and prey importance: a new graphical analysis. Journal of Fish Biology, 36(2): 261-263.

Diario Oficial de la Federación (DOF). 2015. Proyecto de modificación a la norma oficial mexicana NOM-029PESC-2006. Pesca responsable de tiburones y rayas. Especificaciones para su aprovechamiento.

Driggers, W., Campbell, M., Hoffmayer, E. \& Ingram Jr., G. 2012. Feeding chronology of six species of carcharhinid sharks in the western North Atlantic Ocean as inferred from longline capture data. Marine Ecology Progress Series, 465: 185-192. doi: 10.3354/meps09901

Drymon, J.M., Powers, S.P. \& Carmichael, R.H. 2012. Trophic plasticity in the Atlantic sharpnose shark (Rhizoprionodon terraenovae) from the north-central Gulf of Mexico. Environmental Biology of Fishes, 95: 21-35. doi: 10.1007/s10641-011-9922-Z
Ellis, J.K. 2003. Diet of the sandbar shark, Carcharhinus plumbeus, in Chesapeake Bay and adjacent waters. M.Sc. Tesis, The College of William and Mary, Williamsburg, $90 \mathrm{pp}$.

Ferry, L.A. \& Cailliet, G.M. 1996. Sample size and data analysis: are we characterizing and comparing diet properly? In: MacKinlay, D. \& Shearer, K. (Eds.). Feeding ecology and nutrition in fish. Proceedings of the Symposium on the Feeding Ecology and Nutrition in Fish. International Congress on the Biology of Fishes. American Fisheries Society, Maryland, pp. 7180.

Froese, R. \& Pauly, D. 2003. Dynamics of overfishing. In: Lozán, J.L., Rachor, E., Sundermann, J. \& Von Westernhagen, H. (Eds.). Warnsignale aus Nordsee und Wattenmeer-eine aktuelle Umweltbilanz. GEO, Hamburg, pp. 288-295.

Galván-Magaña, F., Nienhuis, H.J. \& Klimley, A.P. 1989. Seasonal abundance and feeding habits of sharks of the lower Gulf of California, México. California Fish and Game, 75(2): 74-84.

Galván-Magaña, F. 1999. Relaciones tróficas ínterespecificas de la comunidad de depredadores epipelágicos del Océano Pacífico Oriental. Tesis Doctoral. CICESE, Ensenada, B.C.

García, A.M. 2014. Uso de recursos tróficos por Rhizoprionodon terraenovae y Sphyrna tiburo, en el sureste del Golfo de México. Tesis de Maestría, Universidad Veracruzana, Facultad de Ciencias Biológicas y Agropecuarias, Campus Tuxpan, Veracruz.

García-Godos, N.I. 2001. Patrones morfológicos del otolito sagita de algunos peces óseos del mar peruano. Instituto del Mar de Perú, Callao.

Gelsleichter, J., Musick, J.A. \& Nichols, S. 1999. Food habits of the smooth dogfish, Mustelus canis, dusky shark, Carcharhinus onscurus, Atlantic sharpnose shark, Rhizoprionodon terraenovae, and the sand tiger, Carcharias taurus, from the northwest Atlantic Ocean. Environmental Biology of Fishes, 54: 205-217.

Hart, P.J.B. \& Ison, S. 1991. The influence of prey size and abundance, and individual phenotype on prey choice by the three-spined stickleback, Gasterosteus aculeatus. Journal of Fish Biology, 38: 359-372.

Heithaus, M.R., Frid, A., Wirsing, A.J. \& Worm, B. 2008. Predicting ecological consequences of marine top predator declines. Trends in Ecology and Evolution, 23(4): 202-210.

Heithaus, M.R., Frid, A., Vaudo, J., Worm, B. \& Wirsing, A.J. 2010. Unraveling the ecological importance of elasmobranchs. In: Carrier, J.C., Musick, J.A. \& Heithaus, M.R. (Eds.). Sharks and their relatives. II. Biodiversity, adaptive physiology, and conservation. CRC Press, Boca Raton, pp. 611-637. 
Herrera-Silveira, J.A. \& Morales-Ojeda, S.M. 2010. Chapter 13: Subtropical karstic coastal, lagoon assessment, southeast Mexico. The Yucatan Peninsula Case. In: Kennish, M.J. \& Paerl, H.W. (Eds.). Coastal lagoons. critical habitats of environmental change. Rutgers University, New Jersey, pp. 307-333.

Hobday, A.J., Young, J.W., Abe, O., Costa, D.P., Cowen, R.K., Evans, K., Gasalla, M.A., Kloser, R., Maury, O. \& Weng, K.C. 2013. Climate impacts and oceanic top predators: moving from impacts to adaptation in oceanic systems. Reviews in Fish Biology and Fisheries, 23: 537-546.

Hoffmayer, E.R. \& Parsons, G.R. 2003. Food habits of three shark species from the Mississippi sound in the northern Gulf of Mexico. Southeastern Naturalist, 2(2): 271-280.

Kaschner, K., Kesner-Reyes, K., Garilao, C., Rius-Barile, J., Rees, T. \& Froese, R. 2016. AquaMaps: predicted range maps for aquatic species. World Wide Web electronic publication. [www.aquamaps.org]. Reviewed: July 10, 2019.

Klimley, A.P. 1983. Social organization of schools of the scalloped hammerhead, Sphyrna lewini (Griffith \& Smith), in the Gulf of California. Ph.D. Thesis, University of California, San Diego.

Kotas, J.E., Santos S., Guedes de Azevedo, V., Meneses de Lima, J.H., Dias, N.J. \& Fernandes, L.C. 2000. Observations on shark by-catch in the monofilament longline fishery off southern Brazil and the National Ban on finning. Shark conference 2000, Honolulu, Hawaii, February 21-24.

Krebs, C.J. 1999. Ecological methodology. Addison Wesley, California.

Labropoulou, M. \& Eleftheriou, A. 1997. The foraging ecology of two pairs of congeneric demersal fish species: importance of morphological characteristics in prey selection. Journal of Fish Biology, 50: 324340. doi: 10.1111/j.1095-8649.1997.tb01361.x

Laurs, R.M. \& Lynn, R.J. 1977. Seasonal migration of north Pacific albacore. (Thunnus alalunga) into North American coastal waters: distribution. Relative abundance and association with transition Zone waters. Fisheries Bulletin, 75(4): 795-822.

Longhurst, A.R. 1967. The pelagic phase of Pleuroncodes planipes Stimpson (Crustacea, Galatheidae) in the California Current. CalCOFI Investigations Reports, 11: 142-154.

Lowe, C.G., Wetherbee, B.M., Crow, G.L. \& Tester, A.L. 1996. Ontogenetic dietary shifts and feeding behaviour of the tiger shark, Galeocerdo cuvier, in Hawaiian waters. Environmental Biology of Fishes, 47: 203-211.
Márquez-Farías, J.F., Corra-Espinosa, D. \& CastilloGéniz, J.L. 2005. Observations on the biology of the Pacific sharpnose shark, Rhizoprionodon longurio (Jordan \& Gilbert, 1882), captured in southern Sinaloa, México. Journal of Northwest Atlantic Fisheries Science, 35: 107-114.

Martínez-Cruz, L.E., Zea-de la Cruz, H., Oviedo-Pérez, L., Morales-Parra, L. \& Balan-Che, L. 2016. Aspectos biológico-pesqueros del cazón tutzún Rhizoprionodon terraenovae, en las costas de Campeche, México. Ciencia Pesquera, 24: 23-35.

Murdy, E.O., Birdsong, R. \& Musick, J.A. 1997. Fishes of the Chesapeake Bay. Smithsonian Institution, Washington.

Musick, J.A.S., Branstetter, S. \& Colvocoresses, J.A. 1993. Trends in shark abundance from 1974 to 1991 for the Chesapeake Bight region of the U.S. Mid Atlantic coast. NOAA Technical Report, NMFS Circular, 115: 1-18.

Myers, A.R., Baum, J.K., Shepherd, T.D., Powers, S.P. \& Peterson, C.H. 2007. Cascading effects of the loss of apex predatory sharks from a coastal ocean. Science, 315: 1846-1850.

Navia, A.F., Mejía-Falla, P.A. \& Giraldo, A. 2007. Feeding ecology of elasmobranch fishes in coastal waters of the Colombian Eastern Tropical Pacific. BMC Ecology, 7(1): 8. doi: 10.1186/1472-6785-7-8

Navia-López, A.F. 2013. Función ecológica de tiburones y rayas en un ecosistema costero tropical del Pacífico colombiano. Thesis Doctorado, CICIMAR-IPN, La Paz, 172 pp.

Nevárez-Martínez, M.O., Morales-Bojorquez, E., Cervantes-Valle, C., Santos-Molina, J.P. \& LópezMartínez, J. 2010. Population dynamics of the jumbo squid (Dosidicus gigas) in the 2002-2008 fishing seasons off Guaymas, Mexico. Fisheries Research, 106: 132-140.

Odum, E.P. 1970. Optimum population and environment: a Georgian microcosm. Current History, 58: 355-359.

Oksanen, J., Guillaume-Blanchet, F., Kindt, R., Legendre, P., Minchin, P.R., O'Hara, R.B., Simpson, G.L., Solymos, P., Henry, M., Stevens, H. \& Warner, H. 2015. Vegan: Community Ecology Package. R Package version 2.2-1. [http://CRAN.R-project.org/ package=vegan]. Reviewed: July 2, 2020.

Olson, R.J. \& Boggs, C.H. 1986. Apex predation by yellowfin tuna (Thunnus albacares): independent estimates from gastric evacuation and stomach contents, bioenergetics, and cesium concentrations. Canadian Journal of Fisheries and Aquatic Sciences, 439: 1760-1775.

Ovchinnikov, V.V. 1970. Swordfishes and billfishes in the Atlantic Ocean: ecology and functional morphology. Israel Program for Scientific Translations, Jerusalem. 
Parsons, G.R. \& Hoffmayer, E.R. 2005. Seasonal changes in the distribution and relative abundance of the Atlantic sharpnose shark Rhizoprionodon terraenovae in the north central Gulf of Mexico. Copeia, 2005(4): 914-920.

Pauly, D. 1998. Tropical fishes: patterns and propensities. Journal of Fish Biology, 53: 1-17.

Pérez-Farfante, I. \& Kensley, B. 1997. Penaeoid and Sergestoid shrimps and prawns of the world. Keys and diagnoses for the families and genera. Mémoires du Muséum National d'Histoire Naturelle, Paris, 175: 233 pp.

Pérez-Jiménez, J.C. \& Méndez-Loeza, I. 2015. The smallscale shark fisheries in the southern Gulf of Mexico: understanding their heterogeneity to improve their management. Fisheries Research, 172: 96-104. doi: 10.1016/j.fishres.2015.07.004

Pielou, E.C. 1975. Ecological diversity. John Wiley and Sons, New York.

Pinkas, L., Oliphant, M.S. \& Iverson, I.L.K. 1971. Food habits of albacore, bluefin tuna, and bonito in California waters. Fishery Bulletin, 152: 1-105.

Preti, A., Smith, S.E. \& Ramon, D.A. 2001. Feeding habits of the common thresher (Alopias vulpinus) sampled from the California-based drift gillnet fishery, 199899. CalCOFI Investigations Reports, 42: 145-152.

Priede, I.G., Froese, R., Bailey, D.M., Bergstad, O.A., Collins, M.A., Dyb, J.E., Henriques, C., Jones, E.G. \& King, N. 2006. The absence of sharks from abyssal regions of the world's oceans. Proceedings of the Royal Society Part B, 273: 1435-1441. doi: 10.1098/rspb. 2005.3461

R Core Team. 2013. R: a language and environment for statistical computing. R Foundation for Statistical Computing. [http://www.R-project.org]. Reviewed: June 12, 2019.

Southward, A.J. \& Boalch, G.T. 1994. The effect of changing climate on marine life: past events and future predictions. Exeter Maritime Studies, 9: 101-143.

Southward, A.J., Hawkins, S.J. \& Burrows, M.T. 1995. Seventy years observations of changes in distribution and abundance of zooplankton and intertidal organisms in the western English Channel in relation to rising sea temperature. Journal of Thermal Biology, 20: $127-155$.

Springer, S. 1967. Social organization of shark populations. In: Gilbert, P.W., Mathewson R.F. \& Rall, D.P. (Eds.). Sharks, skates, and rays. Johns Hopkins University Press, Baltimore, pp. 149-174.

Steel, R.G.D. \& Torrie, J.H. 1992. Bioestadística. Principios y procedimientos. Editorial Graf América, Ciudad de México.
Stergiou, K.I. \& Fourtouni, H. 1991. Food habits, ontogenetic diet shift and selectivity in Zeus faber Linnaeus, 1758. Journal of Fish Biology, 39: 589-603.

Stevens, J.D., Bonfil, R., Dulvy, K. \& Walker, P.A. 2000. The effects of fishing on sharks, rays, and chimaeras (chondrichthyans) and the implications for marine ecosystems. ICES Journal of Marine Science, 57: 476494.

Stillwell, C.E. \& Kohler, N.E. 1982. Food, feeding habits and estimates of daily ration of the Shortfin Mako (Isurus oxyrinchus) in the northwest Atlantic. Canadian Journal of Fisheries and Aquatic Sciences, 39: 407-414.

Tapia-González, F.U., Herrera-Silveira, J.A. \& AguirreMacedo, M.L. 2008. Water quality variability and eutrophic trends in karstic tropical coastal lagoons of the Yucatán Peninsula. Estuarine Coastal and Shelf Science, 76: 418-430.

Tavares, M. 2002. Crustaceans. In: The living marine resources of the Western Central Atlantic. Volume 1: introduction, mollusks, crustaceans, hagfishes, sharks, batoid fishes, and chimaeras. FAO species identification guide for fishery purposes. FAO, Rome, pp. 245-343.

Treloar, M.A., Laurenson, L.J.B. \& Stevens, J.D. 2007. Dietary comparisons of six skate species (Rajidae) in southeastern Australian waters. Environmental Biology of Fishes, 80: 181-196.

Tricas, T.C. 1979. Relationships of the blue shark, Prionace glauca, and its prey species near Santa Catalina Island, California. Fishery Bulletin, 77(1): 175-182.

Trowbridge, C.D. 1991. Diet specialization limits herbivorous sea slug's capacity to switch among food species. Ecology, 72(5): 1880-1888.

Vaudo, J.J. \& Heithaus, M.R. 2009. Spatiotemporal variability in a sandflat elasmobranch fauna in Shark Bay, Australia. Marine Biology, 156: 2579-2590.

Vögler, R., Milessi, A.C. \& Duarte, L.O. 2009. Changes in trophic level of Squatina guggenheim with increasing body length: relationships with type, size and trophic level of its prey. Environmental Biology of Fishes, 84: 41-52.

Weihaupt, J.G. 1984. Exploración de los océanos. Introducción a la oceanografía. Compañía Editorial Continental, Ciudad de México.

Wetherbee, B.M. \& Cortés, E. 2004. Food consumption and feeding habits. In: Carrier, J.C., Musick, J.A. \& Heithaus, M.R. (Eds.). Biology of sharks and their relatives. CRC Press, Boca Raton, pp. 225-246.

Wetherbee, B.M., Gruber, S.H. \& Cortés, E. 1990. Diet feeding habits, digestion, and consumption in sharks, 
with special reference to the lemon shark, Negaprion brevirostris. NOAA Technical Report, 90: 29-47.

Wolff, G.A. 1984. Identification and estimation of size from the beaks of 18 species of cephalopods from the Pacific Ocean. NOAA Technical Report, 17: 50 pp.

Received: 10 September 2019; Accepted: 4 February 2020
Yáñez-Arancibia, A. \& Day, J.W. 1982. Ecological characterization of Terminos Lagoon, a tropical lagoon-estuarine system in the southern Gulf of Mexico. Oceanológica Acta, 1: 431-440. 